\title{
Bioactivity of Viscoelastic Ormosil-Type Organic-Inorganic Hybrids Containing Colloidal Silica Particles
}

\author{
Yasushi ABURATANI, Kanji TSURU, ${ }^{*}$ Satoshi HAYAKAWA and Akiyoshi OSAKA \\ Biomaterials Laboratory, Faculty of Engineering, Okayama University, 3-1-1, Tsushima-Naka, Okayama-shi 700-8530
}

\section{コロイダルシリカを含有した粘弾性的 Ormosil 型有機一無機ハイブリッド材料の生体活性 油谷 康·都留寛治·早川 聡·尾坂明義 \\ 岡山大学工学部生物機能工学科生体素材工学研究室, 700-8530 岡山市津島中 3-1-1}

\begin{abstract}
Synthesized were organically modified silicate (ORMOSILs) hybrids containing colloidal silica as an ingredient, starting from poly (dimethylsiloxane) (PDMS), tetraethoxysilane (TEOS) and calcium nitrate through sol-gel processing. The effects of pre-hydrolysis of TEOS on mechanical strength and viscoelasticity were examined. A sample of composition PDMS/TEOS $=0.60$ (molar ratio) with pre-hydrolysis of TEOS showed about $65 \%$ maximum failure strain. Thus obtained hybrid exhibited a peak at around $-75^{\circ} \mathrm{C}$ in the storage modulus-temperature curve of the hybrid, due to transverse movements of the PDMS chains. This hybrid, heated at $200^{\circ} \mathrm{C}$ deposited apatite within $1 \mathrm{~d}$ in the simulated body fluid of the Kokubo recipe.
\end{abstract}

[Received November 28, 2002; Accepted February 7, 2003]

Key-words : Compressive strength, Viscoelasticity, Bioactivity, Apatite, Organic-inorganic hybrid, Sol-gel

\section{Introduction}

Bioactive ceramics have already occupied important positions in bone-repairing materials. ${ }^{1)}$ However, high elastic modulus and brittleness is one of the possible factors that prevent them from not only extensive use as bone substitutes but also as soft tissue replacements. Therefore, new types of bioactive materials with widely correspondence for the mechanical property of a body part are desired. For soft tissue replacement, organic-inorganic hybrids are promising. Some of the hybrids have been derived from poly (dimethylsiloxane) (PDMS) and tetraethoxysilane (TEOS) and denoted as organically modified silicates (Ormosils). They showed a variety of glass-like and rubber-like properties dependent on controlled mixing ratios of organic and inorganic component in the precursor solutions. ${ }^{2), 3)}$ As the calcium ions are incorporated into the organically modified silicate structure, the hybrids formed apatite $^{3), 4)}$ in a simulated body fluid (SBF) of the Kokubo recipe. ${ }^{5)}$

On these bases, Aburatani et al. ${ }^{6), 7)}$ conducted a preliminary experiment to prepare a few flexible and bioactive Ormosils-type hybrids containing colloidal silica, where colloidal silica was one of the materials reinforcing silicone. Those materials may fit well with defects to be repaired, e.g., cartilaginous, cover the defects to protect from infiltration of bacteria, or contribute regeneration of the deficit tissue. In the experiment, ${ }^{6,7)}$ TEOS, one of the component chemicals, was mixed together with the other components and refluxed to yield precursor sols, and the sols were then aged to obtain the targeted hybrids. It was found that the maximum failure strain increased as PDMS content increased. Moreover, the hybrids with larger PDMS contents did not deposit apatite on them. As it is believed that the silanol group is one of the essential chemical species, hybrids involving more silanol groups would be more bioactive. Thus, one might expect that a precursor sol involving well-hydrolyzed TEOS would derive hybrids that retain more silanol groups in the structure and lead to better bioactivity. Furthermore, it is possible to remove the residual components such as some solvents by heating. Thus, the heating may affect the relative amount of silanol groups. In this study, TEOS therefore subjects to pre-hydrolysis prior to use in preparing the precursor sols, and the effects of the pre-hydrolysis and heating on the bioactivity, viscoelasticity, microstructure, and mechanical strength were investigated.

\section{Materials and methods}

\subsection{Synthesis of the samples}

The starting materials were silanol-terminated PDMS, (with an average molecular weight of 1750), TEOS, and calcium nitrate $\left(\mathrm{Ca}\left(\mathrm{NO}_{3}\right)_{2} \cdot 4 \mathrm{H}_{2} \mathrm{O}\right)$. The molar compositions for the starting materials were TEOS : PDMS : $\mathrm{HCl}: \mathrm{H}_{2} \mathrm{O}$ : $\mathrm{Ca}\left(\mathrm{NO}_{3}\right)_{2}=1: 0.24$ or $0.60: 0.6: 3.0: 0.25$. The colloidal silica content (average primary particle size: $12 \mathrm{~nm}$, Aerosil Japan Co.) was fixed to be 14 mass \% of the total amount of the inorganic and organic components, i.e., the mass ratio colloidal silica/ (TEOS + PDMS + colloidal silica) was kept at 0.14 . The final compositions were expressed as " $\mathrm{CS}_{x} \mathrm{P}_{y}$ " where $x$ denoted the mass ratio of colloidal silica CS; $\mathrm{P}$ represented PDMS, and $y$ denoted the molar ratio PDMS/ TEOS. Figure 1 schematically shows the flow chart of the synthesis. Solution 1 was prepared by dissolving TEOS in
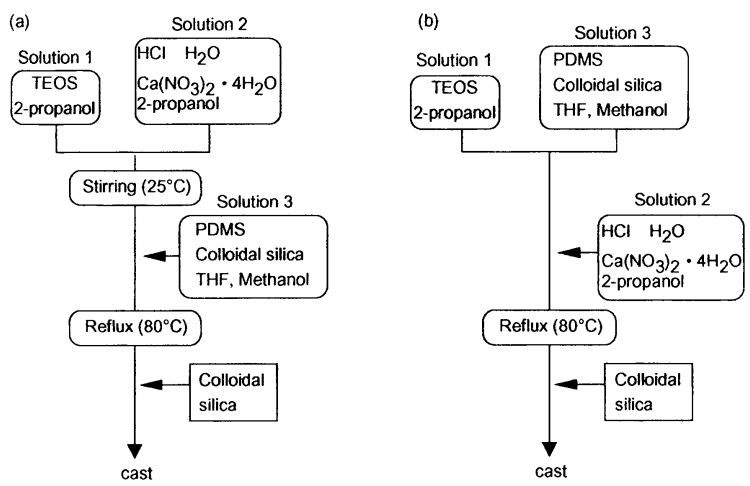

Fig. 1. Flow chart of the synthesis, (a) pre-hydrolysis synthesis, (b) ordinary synthesis. 
Table 1. Molar Ratios of Starting Materials for Preparing Samples

\begin{tabular}{|c|c|c|c|c|c|c|c|c|}
\hline \multirow[t]{2}{*}{ Sample } & \multicolumn{5}{|c|}{ Compositions (molar ratio) } & \multirow{2}{*}{$\frac{\text { Colloidal silica(mass } \%)}{\text { Colloidal silica+TEOS+PDMS }}$} & \multirow{2}{*}{$\begin{array}{l}\text { tirring time at } 25^{\circ} \mathrm{C} \\
\mathrm{S} \quad(\mathrm{min})\end{array}$} & \multirow{2}{*}{$\begin{array}{c}\text { Heat treatment } \\
\left({ }^{\circ} \mathrm{C}\right)\end{array}$} \\
\hline & TEOS & PDMS & $\mathrm{H}_{2} \mathrm{O}$ & $\mathrm{HCl}$ & $\mathrm{Ca}\left(\mathrm{NO}_{3}\right)_{2}$ & & & \\
\hline$\overline{\mathrm{CS}_{14} \mathrm{P}_{0.24}}$ & 1.0 & 0.24 & 3.0 & 0.6 & 0.25 & 14 & - & - \\
\hline $\mathrm{CS}_{14} \mathrm{P}_{0.24-05 m}$ & 1.0 & 0.24 & 3.0 & 0.6 & 0.25 & 14 & 5 & - \\
\hline $\mathrm{CS}_{14} \mathrm{P}_{0.24} 10 \mathrm{~m}$ & 1.0 & 0.24 & 3.0 & 0.6 & 0.25 & 14 & 10 & - \\
\hline $\mathrm{CS}_{14} \mathrm{P}_{0.24} 30 \mathrm{~m}$ & 1.0 & 0.24 & 3.0 & 0.6 & 0.25 & 14 & 30 & - \\
\hline $\mathrm{CS}_{14} \mathrm{P}_{0.60}$ & 1.0 & 0.60 & 3.0 & 0.6 & 0.25 & 14 & - & - \\
\hline $\mathrm{CS}_{14} \mathrm{P}_{0.60 \_30 \mathrm{~m}}$ & 1.0 & 0.60 & 3.0 & 0.6 & 0.25 & 14 & 30 & - \\
\hline $\mathrm{HT} \_\mathrm{CS}_{14} \mathrm{P}_{0.60}$ & 1.0 & 0.60 & 3.0 & 0.6 & 0.25 & 14 & - & 200 \\
\hline $\mathrm{HT} \_\mathrm{CS}_{14} \mathrm{P}_{0.60-30 \mathrm{~m}}$ & 1.0 & 0.60 & 3.0 & 0.6 & 0.25 & 14 & 30 & 200 \\
\hline
\end{tabular}

2-propanol so that the mass ratio 1.56 for 2-propanol/TEOS. Solution 2 was prepared by dissolving appropriate amounts of calcium nitrate, distilled water and a $\mathrm{HCl}$ solution (35 mass\%) into 2-propanol so that the mass ratio 1.56 for 2-propanol/TEOS keeping the molar ratio TEOS: $\mathrm{HCl}: \mathrm{H}_{2} \mathrm{O}: \mathrm{Ca}\left(\mathrm{NO}_{3}\right)_{2}=1: 0.6: 3.0: 0.25$. Pre-hydrolysis of TEOS was carried out by adding solution 2 to solution 1 and stirring at $25^{\circ} \mathrm{C}$ for $5-30 \mathrm{~min}$. After stirring, this mixture was added to solution 3 which PDMS were dissolved in a mixed solvent of methanol and THF so that the weight ratio $1: 0.80: 0.44$ for PDMS : methanol : THF. The final mixture was refluxed under stirring at $80^{\circ} \mathrm{C}$ for $30 \mathrm{~min}$. The amount of colloidal silica was divided into 5 portions, and each portion was then added to the resultant solution every $5 \mathrm{~min}$. After refluxed, the mixtures were quenched to $25^{\circ} \mathrm{C}$ with iced water, casted into containers with a cover, and aged for gelation at $25^{\circ} \mathrm{C}$. After gelation, the hybrid gels were dried at room temperature for $7 \mathrm{~d}$, at $40^{\circ} \mathrm{C}$ for $2 \mathrm{~d}$, and at $60^{\circ} \mathrm{C}$ for $2 \mathrm{~d}$. The samples derived from the sol-gel route involving pre-hydrolysis of TEOS were expressed as $\mathrm{CS}_{x} \mathrm{P}_{y} z \mathrm{~m}$, where " $z$ " denoted the pre-hydrolysis time (min). Some dry gels were further heated up to $200^{\circ} \mathrm{C}$ at a rate for $2^{\circ} \mathrm{C} / \mathrm{min}$ and held at $200^{\circ} \mathrm{C}$ for $2 \mathrm{~h}$. The heat-treated hybrids were denoted as $\mathrm{HT}_{-} \mathrm{CS}_{x} \mathrm{P}_{y} \_\mathrm{m}$, where "HT_" represents "heating at $200^{\circ} \mathrm{C}$." The heating is conducted for driving off water and the solvents from the hybrids. For reference, the gels were also synthesized without the prehydrolysis of stirring of TEOS at $25^{\circ} \mathrm{C}$ as before. $\left..^{6}, 7\right)$ Table 1 indicates the composition of all hybrids employed in the present study.

\subsection{Characterization}

The dry hybrids were shaped to rectangular parallelepipeds. Their compressive strength was measured at room temperature with a universal testing machine (AGS10KNG Autograph, Shimadzu) with a crosshead speed of $1 \mathrm{~mm} / \mathrm{min}$. Dynamic viscoelastic properties of the hybrids were evaluated using a dynamic viscoelastometer (SDM5600-DMS120, Seiko) at $0.5-10 \mathrm{~Hz}$ in the temperature range $-150^{\circ} \mathrm{C}$ to $+250^{\circ} \mathrm{C}$ with a heating rate of $2^{\circ} \mathrm{C} /$ $\min$. The specimen size was about $60 \times 15 \times 2 \mathrm{~mm}^{3}$. The local structure around $\mathrm{Si}$ atoms in the hybrids was investigated by ${ }^{29} \mathrm{Si}$ MAS NMR spectroscopy (VARIAN UNITYINOVA 300, USA) as described elsewhere. ${ }^{8)}$ The spectra were taken for pulverized samples placed in zirconia sample tubes. The spinning rate was about $3.5 \mathrm{kHz}$. The chemical shift was represented in $\delta(\mathrm{ppm})$ with referencing to tetramethylsilane (TMS) by convention. Polydimethylsilane $(\delta=-34.0 \mathrm{ppm}$ versus TMS) was used as the external reference.

Specimens $10 \times 10 \times 1 \mathrm{~mm}^{3}$ in size were polished with
Table 2. Compressive Strength and Maximum Failure Strain of the Samples

\begin{tabular}{lcc}
\hline \multicolumn{1}{c}{ samples } & $\begin{array}{c}\text { Compressive } \\
\text { strength(MPa) }\end{array}$ & $\begin{array}{l}\text { Maximum } \\
\text { failure strain (\%) }\end{array}$ \\
\hline $\mathrm{CS}_{14} \mathrm{P}_{0.24}$ & $5.1 \pm 1.1$ & $41.3 \pm 2.9$ \\
$\mathrm{CS}_{14} \mathrm{P}_{0.24} 05 \mathrm{~m}$ & $2.1 \pm 0.1$ & $36.0 \pm 3.7$ \\
$\mathrm{CS}_{14} \mathrm{P}_{0.24} 30 \mathrm{~m}$ & $1.7 \pm 0.1$ & $36.3 \pm 1.7$ \\
$\mathrm{CS}_{14} \mathrm{P}_{0.60}$ & $0.8 \pm 0.3$ & $63.1 \pm 4.0$ \\
$\mathrm{CS}_{14} \mathrm{P}_{0.60} 30 \mathrm{~m}$ & $1.0 \pm 0.1$ & $62.0 \pm 4.6$ \\
$\mathrm{HT} \mathrm{CS}_{14} \mathrm{P}_{0.60}$ & $0.9 \pm 0.1$ & $61.5 \pm 4.3$ \\
$\mathrm{HT} \_\mathrm{CS}_{14} \mathrm{P}_{0.60 \_} 30 \mathrm{~m}$ & $0.8 \pm 0.1$ & $65.3 \pm 4.0$ \\
\hline
\end{tabular}

\#400 and \#2000 emery paper, gently rinsed with distilled water, and dried. Then they were soaked up to $7 \mathrm{~d}$ in a simulated body fluid of the Kokubo recipe $\left.(\mathrm{SBF})^{5}\right)\left(36.5^{\circ} \mathrm{C}, \mathrm{pH}\right.$ $=7.25$ ). After soaking, the specimens were removed from the SBF and gently washed with distilled water. Concentrations of $\mathrm{Ca}, \mathrm{P}$, or Si in SBF were measured by inductivity coupled plasma emission spectroscopy (ICP; SPS7700, Seiko Electronics) as a function of the soaking period. The surface structure of the specimens was examined by thinfilm X-ray diffraction (TF-XRD; $\mathrm{Cu} \mathrm{K} \alpha$, RAD IIA, Rigaku) equipped with a thin-film attachment. Microstructure of the fracture-surface was observed under a scanning electron microscope (SEM; JEOL JSM-6300) equipped with an energy-dispersive X-ray analyzer (EDX-4, Phillips) after the surfaces were coated with a thin gold film.

\section{Results}

3.1 Mechanical properties and chemical environment of the Si atoms

Table 2 shows compressive strength and maximum strain at failure for the hybrids with and without the pre-hydrolysis. The comparison between $\mathrm{CS}_{14} \mathrm{P}_{0.60}$ and $\mathrm{CS}_{14} \mathrm{P}_{0.60} 30 \mathrm{~m}$ indicates that the pre-hydrolysis causes practically no effects on the mechanical strength for the $\mathrm{CS}_{14} \mathrm{P}_{0.60}$ family, while it reduced the compressive strength of $\mathrm{CS}_{14} \mathrm{P}_{0.24}$ family as well as maximum strain. The comparison of HT_CS ${ }_{14} \mathrm{P}_{0.60}$ with HT_CS ${ }_{14} \mathrm{P}_{0.60}$ 30m indicated that the combination of the pre-hydrolysis and the heating treatment was effective to increase the maximum strain but not affected the compressive strength. The $\mathrm{CS}_{14} \mathrm{P}_{0.60}$ family showed larger maximum strain at failure, about $60-70 \%$, than the other. 

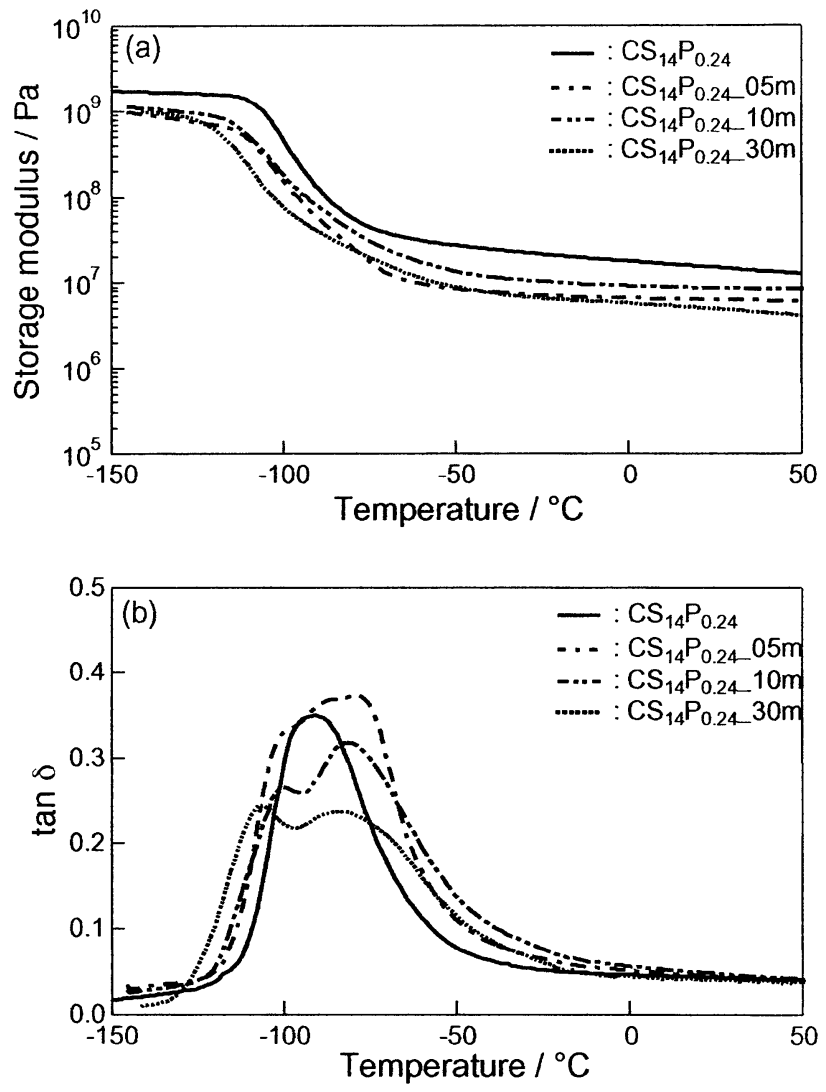

Fig. 2. Temperature dependence of the dynamic mechanical properties of the $\mathrm{CS}_{14} \mathrm{P}_{0.24}$ series at $10 \mathrm{~Hz}$.

Figures 2 (a) and (b) respectively show the storage modulus and $\tan \delta$-temperature profiles for the samples of the $\mathrm{CS}_{14} \mathrm{P}_{0.24}$ family prepared with varied length of prehydrolysis of TEOS. $\mathrm{CS}_{14} \mathrm{P}_{0.24}$ was the greatest of the family members in the storage modulus in the whole temperature range, while the period of the pre-hydrolysis seemed little effective on the modulus for the other members of the $\mathrm{CS}_{14} \mathrm{P}_{0.24}$ family. This agreed well with Table 1 . In contrast, the $\tan \delta$ curves depended on the pre-hydrolysis: A single glass transition $\left(T_{\mathrm{g}}\right)$ peak (the solid curve) was observed at $-90^{\circ} \mathrm{C}$ for $\mathrm{CS}_{14} \mathrm{P}_{0.24}$. The pre-hydrolysis changed the peak into a doublet with maxima at about -110 and $-80^{\circ} \mathrm{C}$. Moreover, the former grew with longer pre-hydrolysis. Figure 3 shows the viscoelastic properties for the samples in the $\mathrm{CS}_{14} \mathrm{P}_{0.60}$ family, i.e., (a) storage modulus and (b) $\tan \delta$. Figure $3(\mathrm{a})$ indicated that all the samples gave similar modulus-temperature profiles in the whole temperature range except that $\mathrm{CS}_{14} \mathrm{P}_{0.60} 30 \mathrm{~m}$ exhibited a little hump (fine-dotted line) extending from -100 to $-40^{\circ} \mathrm{C}$ centered at $-75^{\circ} \mathrm{C}$. The storage modulus above $T_{\mathrm{g}}$ was of a magnitude of $1 \mathrm{MPa}$, indicating that all the hybrids were soft around the body temperature. Fig. 3 (b) exhibited an asymmetrical $T_{\mathrm{g}}$ peak for each sample that a little shifted to lower temperature.

The hybrids consist of PDMS chains and silica blocks depending on the synthesis route. Accordingly, the NMR spectrum was hence composed of two parts.

Figure 4 shows each part of the NMR spectrum of the $\mathrm{CS}_{14} \mathrm{P}_{0.24}$ family with the pre-hydrolysis: The first one, ranging around $-20 \mathrm{ppm}$, is due to $D$ units related to $\mathrm{O}_{2} \mathrm{Si}\left(\mathrm{CH}_{3}\right)_{2}$ groups derived from the PDMS chains. The other around $-100 \sim-110 \mathrm{ppm}$ is due to $Q$ units related to $\mathrm{SiO}_{2}$ structure derived from TEOS and colloidal silica. The
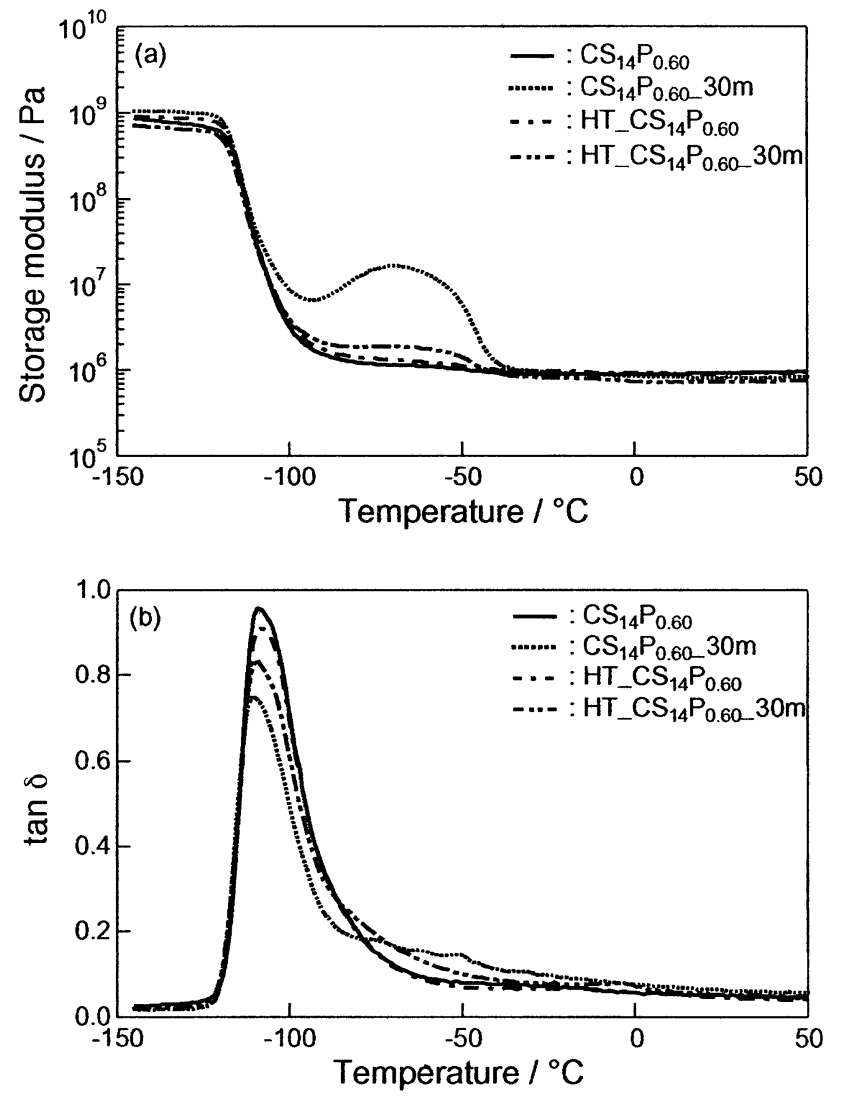

Fig. 3. Temperature dependence of the dynamic mechanical properties of the $\mathrm{CS}_{14} \mathrm{P}_{0.60}$ series at $10 \mathrm{~Hz}$.
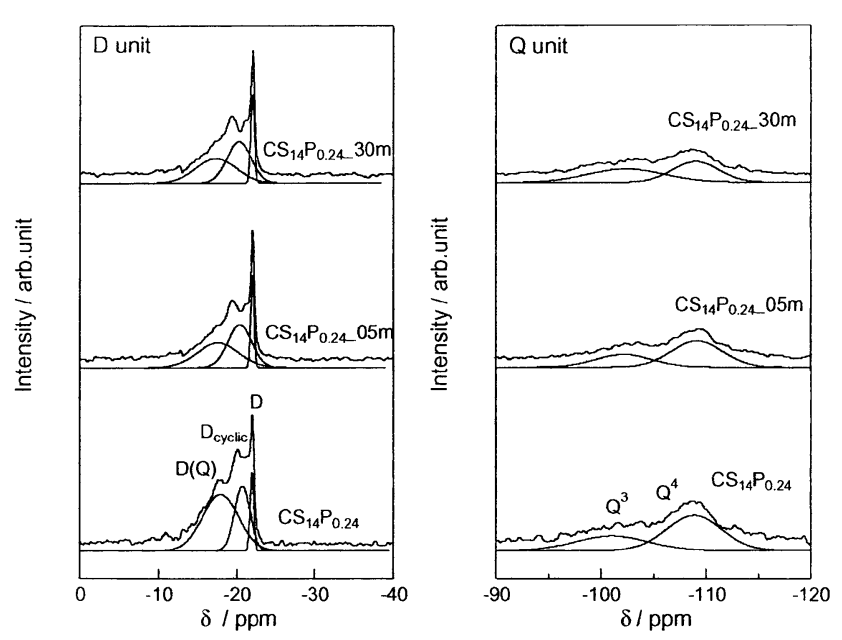

Fig. 4. ${ }^{29} \mathrm{Si}$ MAS NMR spectra of the samples. Each of the deconvoluted components is assigned to a $D$ or $Q$ units as indicated.

$-20 \mathrm{ppm}$ and $-10 \mathrm{ppm}$ peaks were assigned to the $D$ units composing the PDMS chains and the $D(Q)$ units connecting PDMS chains with silica blocks, respectively.9)-11) The -18 ppm peak was assigned to cyclic structures $\left.\left(D_{\text {cyclic }}\right) .12\right)$ Detailed deconvolution $^{6)}$ of the profiles into a few component peaks indicated that both chemical shift and width at half maximum were almost independent of the pre-hydrolysis. Figure 5 plots the relative peak area for each unit as a function of the pre-hydrolysis time. The fraction of $Q^{3}$ increased at the expense of the fraction of $Q^{4}$. The increase in 


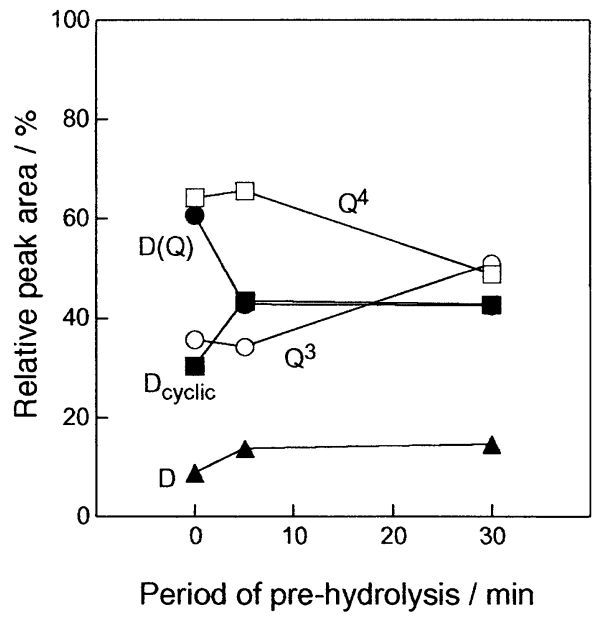

Fig. 5. Relative peak area of $D, D_{\text {cyclic }}, D(Q)$ and $Q^{n}$ for the samples.

$D$ and $D_{\text {cyclic }}$ and decrease in $D(Q)$ indicate that the prehydrolysis of TEOS reduced the PDMS chain-silica particle bonds on the contrary to expectation. The results represented in Fig. 5 well explained the change in the mechanical properties shown in Table 2.

3.2 In vitro bioactivity

Figure 6 shows the TF-XRD patterns of the samples in the $\mathrm{CS}_{14}$ family, i.e., $\mathrm{CS}_{14} \mathrm{P}_{0.24}, \mathrm{CS}_{14} \mathrm{P}_{0.60}, \mathrm{CS}_{14} \mathrm{P}_{0.60} 30 \mathrm{~m}$ and HT_CS ${ }_{14} \mathrm{P}_{0.60} 30 \mathrm{~m}$ after soaking in the SBF up to $7 \mathrm{~d}$. $\mathrm{CS}_{14} \mathrm{P}_{0.24}$ and HT_CS ${ }_{14} \mathrm{P}_{0.60} 30 \mathrm{~m}$ deposited apatite within $1 \mathrm{~d}$ while $\mathrm{CS}_{14} \mathrm{P}_{0.60}$ and $\mathrm{CS}_{14} \mathrm{P}_{0.60} 30 \mathrm{~m}$ did not deposit apatite within $7 \mathrm{~d}$. Though not indicated here, HT_ $\mathrm{CS}_{14} \mathrm{P}_{0.60}$ did not deposit apatite within $7 \mathrm{~d}$, either. Thus, as far as the samples of $\mathrm{CS}_{14} \mathrm{P}_{0.60}$ family were concerned, the heating and prehydrolysis were effective on inducing bioactivity. Figure 7 shows the concentration of $\mathrm{Ca}, \mathrm{P}$ and $\mathrm{Si}$ in $\mathrm{SBF}$ when $\mathrm{CS}_{14} \mathrm{P}_{0.60} 30 \mathrm{~m}$ and HT_CS ${ }_{14} \mathrm{P}_{0.60} 30 \mathrm{~m}$ were soaked. From the previous experiment, ${ }^{13}$ ) the increase in the concentration of $\mathrm{Ca}$ and $\mathrm{Si}$ were attributed to dissolution of each ion from the specimen, while the decrease in that of $\mathrm{Ca}$ and $\mathrm{P}$ were correlated to the deposition of amorphous or crystalline calcium phosphates on the surface. The concentration of $\mathrm{Ca}$ for both samples at first increased until it reached a maximum in $1 \mathrm{~d}$, and then it slightly and gradually decreased. Their Ca concentration profile was different from each other, while the final concentration was irrelevant of the heating treatment. In contrast, the concentration of $\mathrm{P}$ for $\mathrm{CS}_{14} \mathrm{P}_{0.60} 30 \mathrm{~m}$ gradually decreased while that for HT_CS ${ }_{14} \mathrm{P}_{0.60}$ 30m noticeably decreased first then it remained almost constant after $1 \mathrm{~d}$. Since Si was hardly detected in SBF soaked with both specimen, Si was sparingly dissolved from the specimens. The SEM photographs in Fig. 8 compare the surface microstructure of $\mathrm{CS}_{14} \mathrm{P}_{0.60} 30 \mathrm{~m}$ and HT_CS ${ }_{14} \mathrm{P}_{0.60} 30 \mathrm{~m}$ before and after soaking in SBF up to $1 \mathrm{~d}$. Figures 8 (a) and (b) indicated many particles with a microstructure common to apatite that biomimetically deposited out of SBF, though the XRD patterns shown in Fig. 6 could not identify those particles on $\mathrm{CS}_{14} \mathrm{P}_{0.60} 30 \mathrm{~m}$ as apatite.

\section{Discussion}

From the theory of viscoelasticity the materials with greater values of $\tan \delta$ more dissipates a part of the energy loaded to them as the thermal movement of the lattice or bonds is stimulated. In the present hybrids the energy dissipation accompanies activation of transverse movements of
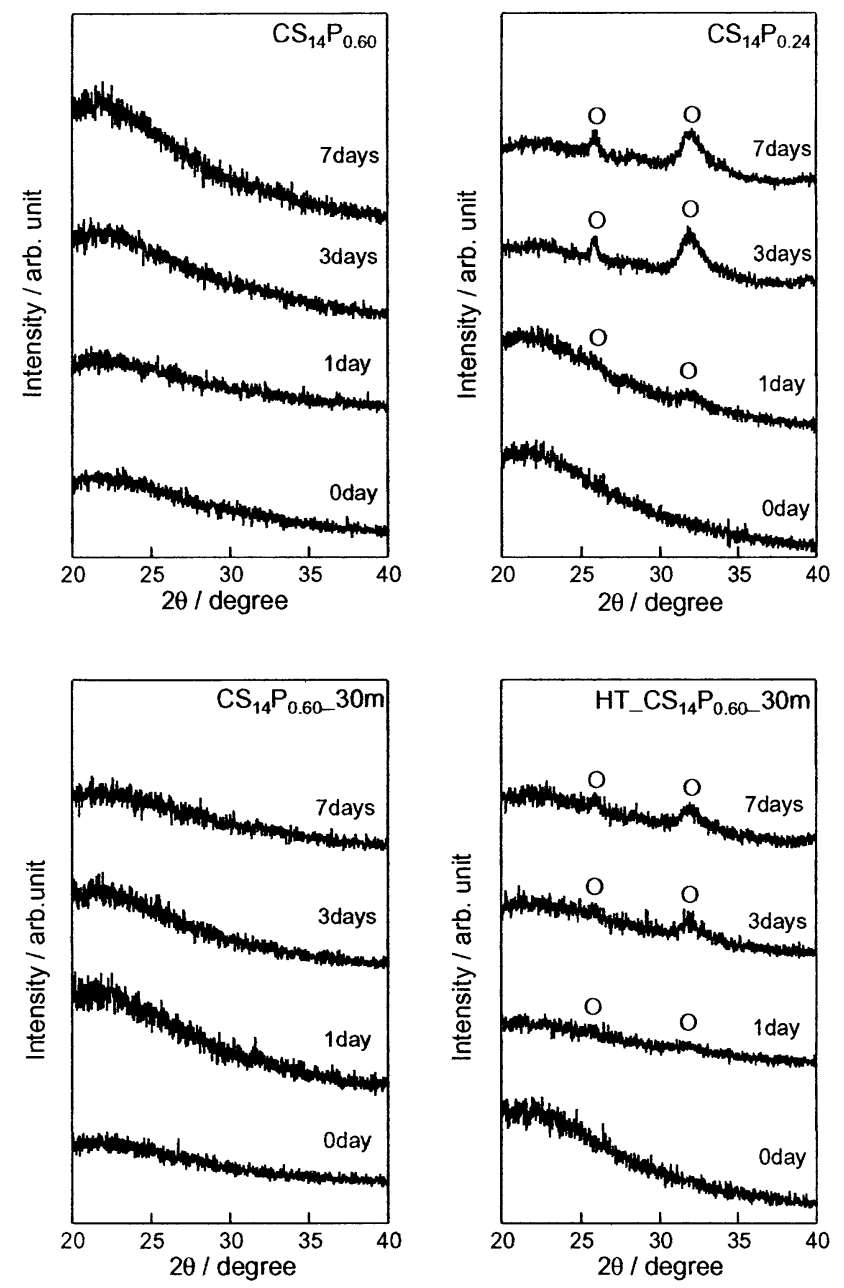

Fig. 6. Thin-film X-ray diffraction patterns for the samples after soaked in SBF up to $7 \mathrm{~d}$. $\bigcirc$ : apatite.
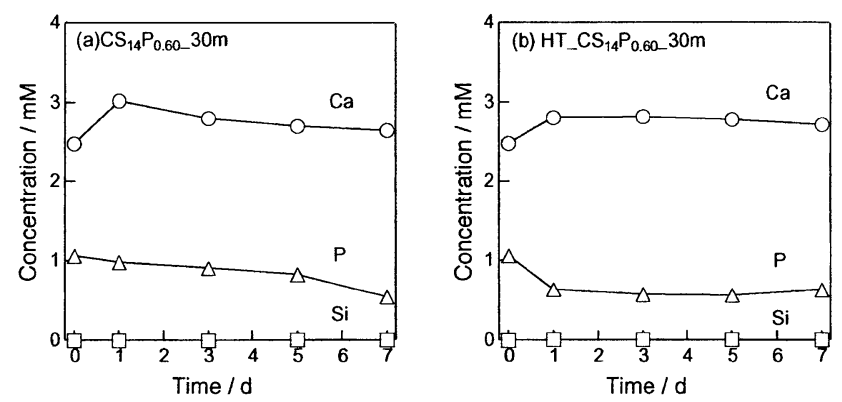

Fig. 7. Concentration of the ions values of SBF as a function of the soaking period.

The concentrations of $\mathrm{Ca}(\mathrm{II}), \mathrm{P}(\mathrm{V})$ and $\mathrm{Si}(\mathrm{IV})$ in $\mathrm{SBF}$ as a function of the soaking period:

(a) $\mathrm{CS}_{14} \mathrm{P}_{0.60} 30 \mathrm{~m}$, (b) HT_CS ${ }_{14} \mathrm{P}_{0.60 \_} 30 \mathrm{~m}$.

the polymeric chains and their segments. It is reasonable to assume that the peak height in the $\tan \delta$ versus temperature curves should represent the relative amount or density of the units whose movements are in resonance with the applied energy. As pointed out previously, ${ }^{7}$ the $\tan \delta$ peak for the $\mathrm{Si}-\mathrm{O}-\mathrm{Si}$ lattice in the silica blocks appears at far below the present temperature range. The temperature for the present doublet peak was thus attributed to the PDMS 

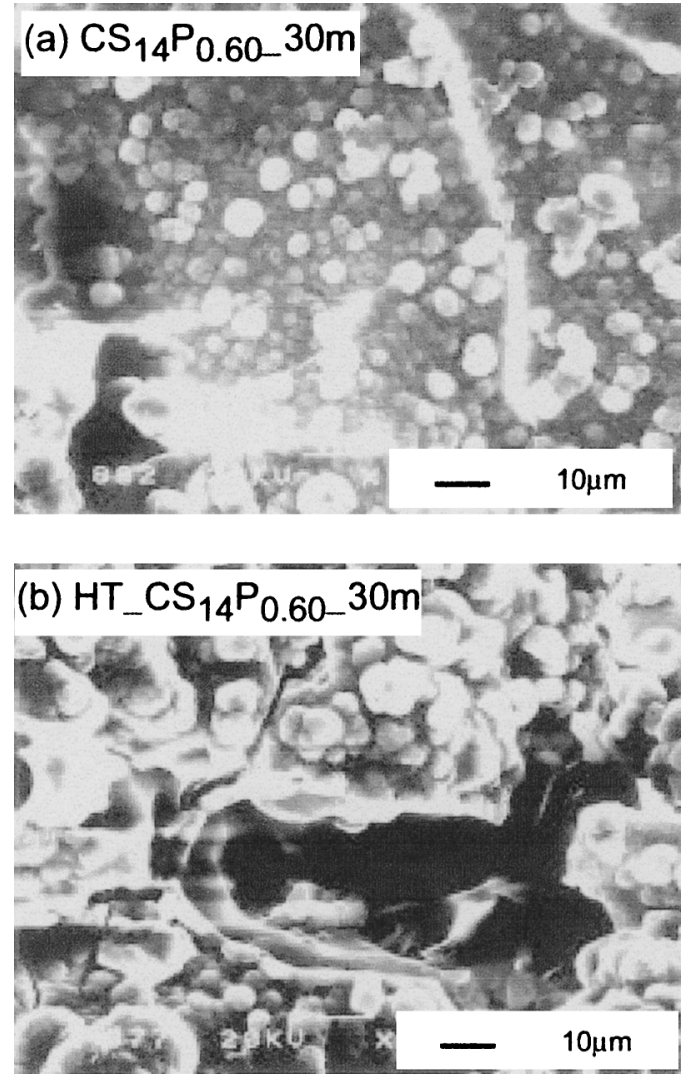

Fig. 8. SEM photographs for the surface microstructure for

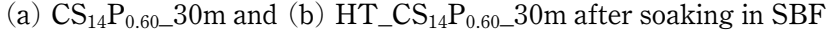
for $1 \mathrm{~d}$.

chains or segments comprising them. Such chain movements will be disturbed or restricted by the nearby solid silica particles. For the $\mathrm{CS}_{14} \mathrm{P}_{0.24}$ family, the lower temperature peak of the doublet at $-110^{\circ} \mathrm{C}$ in Fig. 2 grew with the time of pre-hydrolysis. This is accounted for as the amount of silica particles interacting with the PDMS chains increased. The explanation is described below. Aburatani et al.7) already reported that the relative peak intensity of the $-110^{\circ} \mathrm{C}$ shoulder peak increased with the colloidal silica content. Since the amount of colloidal silica was fixed in this study, the growth of the $-110^{\circ} \mathrm{C}$ peak was then correlated to increase in the silica particles derived from TEOS. It is reasonable to expect that the silica particles from TEOS were nucleated during the pre-hydrolysis and grew in the refluxing solutions. In $\mathrm{CS}_{14} \mathrm{P}_{0.24}$ family, the maximum compressive strength of the pre-hydrolysis samples was lower than that of the hybrid without the pre-hydrolysis. From Figs. 4 and 5, this is attributed to the reduction in the PDMS chain-silica grafting or to reduced in the fraction of $D$ $(Q)$ that leads to agglomeration of the $\mathrm{SiO}_{4}$ units. Thus, since the relative content of TEOS was smaller for the $\mathrm{CS}_{14} \mathrm{P}_{0.60}$ family than in the $\mathrm{CS}_{14} \mathrm{P}_{0.24}$ family, the pre-hydrolysis expected to affect the compressive strength in less magnitude.

The broad peak in the storage modulus curve for $\mathrm{CS}_{14} \mathrm{P}_{0.60} 30 \mathrm{~m}$ found at $-75^{\circ} \mathrm{C}$ is probably related to transverse movements of PDMS chains since the viscoelastic curve of silicone rubber exhibited two-step decrease of the storage modulus on -120 and $\left.-60^{\circ} \mathrm{C} .{ }^{7}\right)$ Thus, this peak was attributed to the increase in $D$ for NMR spectra on $\mathrm{CS}_{14} \mathrm{P}_{0.60}$ family. Moreover, the mobility of PDMS chain was restricted with the increase of PDMS-silica interaction due to the removal of some solvent in the hybrids, hence the peak disappeared by heating.

In $\mathrm{CS}_{14} \mathrm{P}_{0.60}$ family, the hybrids without the pre-hydrolysis of TEOS lost bioactivity as they could not deposit apatite within $7 \mathrm{~d}$ in SBF. In contrast, those synthesized with both the pre-hydrolysis and heat treatment deposited apatite. Thus, essential was the heat-treatment after the synthesis that was effective to provide the hybrids with bioactivity, and the prehydrolysis induced only insignificant effects. Moreover, Figs. 8(a) and (b) indicated the presence of apatite particles on HT_CS ${ }_{14} \mathrm{P}_{0.60} 30 \mathrm{~m}$ and $\mathrm{CS}_{14} \mathrm{P}_{0.60} 30 \mathrm{~m}$, while the particles that appeared on $\mathrm{CS}_{14} \mathrm{P}_{0.60} 30 \mathrm{~m}$ were not identified as apatite by the XRD patterns. Thus, the heating treatment so modified the surface structure as to favor apatite deposition: the modification may include the precipitation of silica particles containing $\mathrm{Ca}$ ions, where the latter may behave like $\mathrm{CaSiO}_{3}$ glass or crystal in SBF. ${ }^{14}$ )

\section{Conclusion}

Organically modified silicate gels were prepared from the PDMS-TEOS-Ca $\left(\mathrm{NO}_{3}\right)_{2} \cdot 4 \mathrm{H}_{2} \mathrm{O}$ solutions. The sample HT_CS ${ }_{14} \mathrm{P}_{0.60} 30 \mathrm{~m}$ exhibited about $65 \%$ distortion. In the $\mathrm{CS}_{14} \mathrm{P}_{0.24}$ family, the pre-hydrolysis samples exhibited a peak at $-80^{\circ} \mathrm{C}$ and a shoulder at $-100^{\circ} \mathrm{C}$ in the $\tan \delta$-temperature curve, while relative height of the shoulder grew with the pre-hydrolysis time. This is accounted for by the relative increase in PDMS-silica particle interaction. HT_CS ${ }_{14} \mathrm{P}_{0.60} 30 \mathrm{~m}$ deposited apatite within $1 \mathrm{~d}$ of soaking in SBF. The pre-hydrolysis and heating induced the ability of apatite formation on the flexible hybrid.

Acknowledgment Financial support of the Okayama Original Entrepreneur Seeds Excavation Enterprise Grant is gratefully acknowledged.

\section{References}

1) Yamamuro T., "An Introduction to Bioceramics," Ed. by Hench, L. L. and Wilson, J., World Scientific, Singapore (1993) pp. 89-103.

2) Hu, Y. and Mackenzie, J. D., J. Mater. Sci., Vol. 27, pp. 4415-4420 (1992).

3) Tsuru, K., Ohtsuki, C., Osaka, A., Iwamoto, T. and Mackenzie, J. D., Proc. Mater. Res. Soc. Symp., Vol. 435, Materials Research Society (1996) pp. 403-408.

4) Tsuru, K., Ohtsuki, C., Osaka, A., Iwamoto, T. and Mackenzie, J. D., J. Mater. Sci., Mater. Med., Vol. 8, pp. 157-161 (1997).

5) Cho, S. B., Nakanishi, K., Kokubo, T., Soga, N., Ohtsuki, C., Nakamura, T., Kitsugi, T. and Yamamuro, T., J. Am. Ceram. Soc., Vol. 78, pp. 1769-1774 (1995).

6) Aburatani, Y., Hayakawa, S., Ohtsuki, C. and Osaka, A., "Bioceramics, Vol. 12," Ed. by Ohgushi, H., Hastings, G. W. and Yoshikawa, T., World Scientific (1999) pp. 457-460.

7) Aburatani, Y., Tsuru, K., Hayakawa, S. and Osaka, A., Mater. Sci. Eng. C, Vol. 20, pp. 195-198 (2002)

8) Ren, L., Tsuru, K., Hayakawa, S. and Osaka, A., J. Non-Cryst. Solids, Vol. 285, pp. 116-122 (2001).

9) Babonneau, F., Polyhedron, Vol. 13, pp. 1123-1130 (1994).

10) Babonneau, F., Gualandris, U. and Pauthe, M., Proc. Mater. Res. Soc. Symp., Vol. 435, Materials Research Society (1996) pp. 119-130.

11) Iwamoto, T., Morita, K. and Mackenzie, J. D., J. Non-Cryst. Solids, Vol. 159, pp. 65-72 (1993).

12) Tsuru, K., Aburatani, Y., Yabuta, T., Hayakawa, S., Ohtsuki, C. and Osaka, A., J. Sol-Gel Sci. Technol., Vol. 21, pp. 89-96 (2001).

13) Ohtsuki, C., Kokubo, T. and Yamamuro, T., J. Non-Cryst. Solids, Vol. 143, pp. 84-92 (1992).

14) Ohtsuki, C., Kokubo, T., Takatsuka, K. and Yamamuro, T., J. Ceram. Soc. Japan (Seramikkusu Ronbunshi), Vol. 99, pp. 1-6 (1991) 